Nowoczesne Systemy Zarządzania

Zeszyt 12 (2017), nr 1 (styczeń-marzec)

ISSN 1896-9380, s. 119-128

Modern Management Systems

Volume 12 (2017), No. 1 (January-March)

ISSN 1896-9380, pp. 119-128
Instytut Organizacji i Zarządzania

Wydział Cybernetyki

Wojskowa Akademia Techniczna

w Warszawie

Institute of Organization and Management

Faculty of Cybernetics

Military University of Technology

\title{
Aspekty marketingowe w zarządzaniu zasobami ludzkimi
}

\section{Marketing aspects in human resource management}

\author{
Edyta Bombiak \\ Uniwersytet Przyrodniczo-Humanistyczny w Siedlcach \\ Wydział Nauk Ekonomicznych i Prawnych \\ e-mail: ebombiak@wp.pl
}

\begin{abstract}
Abstrakt: W gospodarce opartej na wiedzy kapitał ludzki to najcenniejszy zasób będący w dyspozycji organizacji. W tym kontekście wyzwaniem dla pracodawców staje się przyciąganie i zatrzymanie utalentowanych pracowników. Na dzisiejszym, coraz bardziej wymagającym rynku pracy, niezbędna staje się dbałość o dobry wizerunek firmy, co skutkuje rozwojem funkcji marketingowej zarządzania zasobami ludzkimi. Istotną rolę odgrywa tu etap rekrutacji jako jeden z najbardziej widocznych na zewnątrz działań przedsiębiorstwa. Z marketingowego punktu widzenia zarówno oferta zatrudnienia, jak i cały proces rekrutacyjny powinny być atrakcyjne, aby zainteresować kandydatów i zachęcić do aktywności. Wymaga to sięgania po nowoczesne, dostosowane do oczekiwań kandydatów formy rekrutacji.
\end{abstract}

Słowa kluczowe: zarządzanie zasobami ludzkimi, marketing kadrowy, budowanie wizerunku pracodawcy

Abstract: In the knowledge economy human capital is the most precious resource at the disposal of the organization. In this context, the challenge for employers is to attracting and retaining talented employees. In today's increasingly demanding labor market, it becomes necessary to care for the good image of the company, resulting in the development of marketing functions of human resource management. An essential role in the recruitment stage as one of the most visible outside the company's activities. From a marketing point of view of both the offer of employment and the entire recruitment process should be attractive enough to attract candidates and encourage them to be active. This requires recourse to modern, tailored to the expectations of candidates forms of recruitment.

Keywords: human resource management, marketing recruitment, employer branding 


\section{Wstęp}

Charakterystyczną cechą współczesnej gospodarki jest nasilająca się konkurencja. Dotyczy ona zarówno rynku produktów i usług, jak też rynku pracy. W gospodarce opartej na wiedzy przedsiębiorstwa dążą do zdobycia pozycji konkurencyjnej, poprzez wykorzystanie swoich najcenniejszych zasobów, tj. pracowników, określanych współcześnie mianem kapitału ludzkiego. Jednak, aby sprostać oczekiwaniom coraz bardziej wymagających kandydatów, pracodawcy muszą dostosowywać politykę personalną do ich preferencji. Prowadzi to do ewolucji koncepcji zarządzania zasobami ludzkimi. Jednym $\mathrm{z}$ aspektów tego procesu jest rozwój jej funkcji marketingowej. Aby zatrudnić i utrzymać najlepszych specjalistów, organizacje coraz częściej sięgają po narzędzia marketingowe.

Niniejsze opracowanie stanowi refleksję nad możliwością implementacji podejścia marketingowego $\mathrm{w}$ realizacji funkcji personalnej. $\mathrm{W}$ artykule autorka dąży do określenia użyteczności wybranych działań marketingowych w procesie rekrutacji, opierając się na metodzie badawczej, jaką jest analiza krytyczno-poznawcza literatury przedmiotu. $Z$ uwagi na rozległość omawianej problematyki autorka skoncentrowała się na marketingowych aspektach jednego z etapów zarządzania zasobami ludzkimi, tj. procesu rekrutacji. Przesłankę uzasadniającą takie podejście stanowiło przekonanie, iż jest to etap kluczowy z punktu widzenia kształtowania wizerunku pracodawcy jako warunku koniecznego dla pozyskania cennego dla organizacji kapitału ludzkiego.

\section{Istota i etapy zarządzania zasobami ludzkimi}

Każda organizacja jest oferentem określonych wartości adresowanych do różnorodnych odbiorców, w związku z czym pełni równolegle kilka ról rynkowych, wśród których kluczowe miejsce zajmuje rola pracodawcy (Baruk, 2012, s. 107). Procesem, który ma zapewnić właściwą realizację tej roli, jest zarządzanie zasobami ludzkimi.

Zarządzanie zasobami ludzkimi, określane także mianem funkcji personalnej, jest definiowane jako ciąg logicznie ze sobą powiązanych czynności, ukierunkowanych na zapewnienie organizacji w określonym czasie i miejscu wymaganej liczby pracowników o odpowiednich kwalifikacjach oraz tworzenie warunków stymulujących efektywne zachowania zatrudnionego personelu, zgodnie z nadrzędnym celem organizacji (Pocztowski, 1993, s. 20). Rdzeń koncepcji oparty jest na podmiotowym podejściu do człowieka w organizacji, traktowaniu zasobów ludzkich jako składnika aktywów i źródła konkurencyjności oraz powiązaniach między strategią ogólną przedsiębiorstwa a jego strategią personalną w celu ich integracji (Gableta, 2004, s. 167). Istotą koncepcji jest (Pocztowski, 1993, s. 27):

- strategiczna orientacja, wyrażająca się w integracji celów i polityki w sferze zarządzania zasobami ludzkimi z misją i strategią organizacji, 
- decentralizacja decyzji personalnych poprzez przekazywanie większych uprawnień menedżerom liniowym,

- rozwijanie partycypacji pracowników w funkcjonowaniu organizacji,

- indywidualizacja stosunków pracy.

Wśród głównych etapów zarządzania zasobami ludzkimi wymienić należy:

- planowanie zatrudnienia - obejmujące określenie zapotrzebowania na kapitał ludzki w aspekcie zarówno ilościowym, jak i jakościowym;

- pozyskiwanie pracowników - rozumiane jako przyciąganie odpowiedniej puli kandydatów (rekrutacja), ocenę ich potencjału, wybór tego, którego profil kompetencyjny jest najbardziej zbliżony do profilu pożądanego dla wakującego stanowiska pracy (selekcji) oraz podpisanie umowy zatrudnienia i działania adaptacyjne, mające na celu jak najszybsze osiągnięcie optymalnej efektywności zatrudnionego;

- ocenianie pracowników - pozyskiwanie i dostarczanie osobom zainteresowanym informacji o kwalifikacjach, zachowaniach, cechach pracowników oraz ich wynikach pracy, w celu racjonalnego kształtowania polityki personalnej;

- motywowanie pracowników - tworzenie takich warunków i stosowanie takich bodźców, aby możliwe było zaspokojenie potrzeb zatrudnionych przy jednoczesnej realizacji celów organizacji;

- rozwój pracowników - ogół działań, których zadaniem jest wspieranie i realizacja procesów uzupełniania wiedzy oraz doskonalenia umiejętności, $\mathrm{w}$ celu podnoszenia poziomu kompetencji zatrudnionych prowadzącego do wzrostu efektywności ich pracy;

- restrukturyzacja zatrudnienia - dostosowanie stanu i struktury zatrudnienia do potrzeb przedsiębiorstwa w celu optymalizacji jego kosztów.

Nowoczesne podejście do zarządzania zasobami ludzkimi charakteryzuje tzw. orientacja marketingowa zakładająca, że w centrum zainteresowania przedsiębiorstwa znajduje się klient, do którego jest adresowana oferta przedsiębiorstwa. Wdrożenie tej orientacji oznacza postrzeganie pracowników jako klientów wewnętrznych organizacji i wymaga identyfikacji ich potrzeb oraz stworzenia atrakcyjnej oferty je zaspokajającej.

\section{Pracownicy jako interesariusze przedsiębiorstwa w koncepcji marketingu personalnego}

Już w modelu harwardzkim zwrócono uwagę na fakt, że obszary zarządzania zasobami ludzkimi są przedmiotem oddziaływania zarówno interesariuszy zewnętrznych (akcjonariusze, rząd, samorząd, klienci i dostawcy), jak i wewnętrznych (pracownicy, kadra menedżerska, związki zawodowe), zaś ich udział jest niezbędny dla 
podtrzymania i rozwoju działalności przedsiębiorstwa (Bratton, Gold, 2003, s. 20). Współcześnie zauważyć można, że coraz częściej zacierają się różnice między różnymi grupami interesariuszy, bądź też ich role ewoluują. Klienci coraz częściej są włączani w proces zarządzania (Ciepiela, 2014, s. 22) i wykonują zadania przypisywane pracownikom, np. są podmiotem oceniającym w systemie oceny za pomocą metody 360 (Bukowska, 2006, s. 59), zaś pracownicy stają się klientami przedsiębiorstwa.

Traktowanie obecnych i potencjalnych pracowników jako interesariuszy to podstawowe założenie koncepcji marketingu personalnego (kadrowego), definiowanego jako system sposobów postępowania i zachowania przedsiębiorstwa zorientowanego na oczekiwania potencjalnych i zatrudnionych pracowników (Schwan, Seipel, Warszawa 1997, s. 7). Pierwotne i wtórne cele marketingu personalnego ilustruje tabela 1.

Tabela 1. Cele marketingu personalnego

\begin{tabular}{|c|c|}
\hline le & e \\
\hline \begin{tabular}{|l|} 
1) identyfikowanie potrzeb aktualnych \\
pracowników przedsiębiorstwa \\
postrzeganych jako nabywcy \\
wewnętrzni; \\
2) identyfikowanie potrzeb potencjal- \\
nych pracowników przedsiębiorstwa po- \\
strzeganych jako nabywcy zewnętrzni; \\
3) identyfikowanie zmian zachodzą- \\
cych w rozpoznanych potrzebach, \\
określanie ich tempa i kierunków oraz \\
przyczyn; \\
4) zaspokajanie zidentyfikowanych po- \\
trzeb w możliwie najlepszy sposób, tak \\
aby spełnianie oczekiwań aktualnych \\
i potencjalnych pracowników sprzyjało \\
równoczesnemu realizowaniu celów \\
całej organizacji.
\end{tabular} & $\begin{array}{l}\text { ) kreowanie, kształtowanie i utrwalanie wizerunku } \\
\text { rmy jako atrakcyjnego pracodawcy, traktującego } \\
\text { ktualnych i potencjalnych pracowników w kategoriach } \\
\text { ównorzędnych partnerów; } \\
\text { ) pozyskiwanie i utrzymywanie pracowników, } \\
\text { tórych potencjał emocjonalny i intelektualny przesądza } \\
\text { unikalnej osobowości firmy, a tym samym o jej łącznej } \\
\text { artości rynkowej; } \\
\text { 3) stymulowanie aktywności i kreatywności członków } \\
\text { rganizacji, dzięki stworzeniu im warunków pozwala- } \\
\text { çcych na pełne wykorzystywanie ich uświadomionych } \\
\text { nieuświadomionych umiejętności oraz zdolności; } \\
\text { ) nawiązywanie i zacieśnianie więzi z uczestnikami } \\
\text { toczenia firmy, zanim staną się jej rzeczywistymi } \\
\text { racownikami; } \\
\text { ) podtrzymywanie długookresowy relacji z byłymi } \\
\text { racownikami po ich odejściu z firmy lub ich zwolnieniu. }\end{array}$ \\
\hline
\end{tabular}

Źródło: opracowano na podstawie: Baruk, 2005, s. 217

Analizując przedstawione cele stwierdzić można, że marketing personalny obejmuje ogół działań mających na celu zaspokojenie potrzeb interesariuszy zarówno na zewnętrznym, jak i wewnętrznym rynku pracy. Marketing wewnętrzny jest skierowany do już zatrudnionych pracowników, zaś zewnętrzny do kandydatów, których cechuje duża swoboda wyboru dostawcy produktów personalnych, gdyż potencjalny pracownik może ubiegać się o pracę w różnych organizacjach (Baruk, 2014, s. 55). Grupa odbiorców zewnętrznych, zdaniem A.I. Baruk obejmuje kilka subsegmentów (Baruk, 2006, s. 57):

- pracowników potencjalnych, obecnie niepracujących w przedsiębiorstwie, ale zatrudnionych w nim w przeszłości (byli pracownicy); 
- pracowników potencjalnych, którzy przynajmniej raz brali udział w prowadzonych przez firmę usługową działaniach rekrutacyjnych jako kandydaci do pracy, ale nie zostali wówczas zatrudnieni (byli kandydaci);

- pracowników potencjalnych, którzy dotychczas nigdy nie mieli bezpośredniego kontaktu $\mathrm{z}$ daną firmą, ale posiadają potencjał intelektualny, którego pozyskanie w przyszłości byłoby korzystne dla firmy;

- odbiorców pośrednich, którymi są członkowie rodzin pracowników;

- przyjaciół i znajomych pracowników, którzy również tworzą grupę odbiorców pośrednich.

Można zatem stwierdzić, że zakres oddziaływania marketingu personalnego jest szeroki, a krąg jego interesariuszy różnorodny.

Należy podkreślić, że marketing personalny wiąże się z nowym podejściem do pracowników, a jego wdrożenie w obszarze funkcji personalnej zapewnia nowe perspektywy i narzędzia polityki kadrowej (Zbiegień-Maciąg, 1996, s. 16). W koncepcji marketingu personalnego praca staje się bowiem elementem konkurencyjnej gry rynkowej, zaś kompozycja marketingowa 5P stanowi narzędzie wykorzystywania strategii marketingowej do podejmowania decyzji personalnych. W koncepcji marketingu personalnego rekrutacja to proces sprzedaży specyficznego towaru, jakim jest posada, zaś oczekiwaną ceną są kompetencje pracownika (tab. 2). Oznacza to również rozszerzenie tradycyjnej roli rekrutera, który odpowiada nie tylko za pozyskanie talentów, ale także za budowanie pozycji konkurencyjnej firmy na rynku pracy.

Tabela 2. Model 5P w marketingu personalnym

\begin{tabular}{|c|c|}
\hline Elementy marketingu-mix & Składniki marketingu personalnego \\
\hline Product (produkt) & Stanowisko pracy \\
\hline Place (dystrybucja) & Źródła i formy (kanały dystrybucji informacji) rekrutacji \\
\hline Price (cena) & Korzyści z objęcia stanowiska, kwalifikacje pracownika \\
\hline Promotion (promocja) & $\begin{array}{r}\text { Wykorzystanie odpowiednich form i narzędzi rekrutacji, } \\
\text { w celu wywołania zainteresowania na rynku pracy }\end{array}$ \\
\hline Personnel (ludzkie) & Specjaliści ds. karowych/kandydaci/rynek pracy \\
\hline
\end{tabular}

Źródło: Listwan, 2010, s. 119

Analiza specyfiki oraz kręgu interesariuszy będących przedmiotem zainteresowania marketingu personalnego pozwala na sformułowanie wniosku, że wdrożenie tej koncepcji oznacza istotne rozszerzenia zakresu zarządzania zasobami ludzkimi. Objęcie oddziaływaniem polityki personalnej osób ubiegających się o zatrudnienie $\mathrm{w}$ organizacji sprzyja budowaniu kapitału relacyjnego, gdyż potencjalni kandydaci, nawet jeżeli nie zasilą kapitału ludzkiego organizacji, to mogą współtworzyć w przyszłości jej kapitał jako klienci. Podejście marketingowe wydaje się szczególnie 
użyteczne w procesie tworzenia kapitału ludzkiego. Wykorzystanie najnowszych trendów marketingowych może bowiem zwiększyć skuteczność prowadzonych procesów rekrutacyjnych i ułatwić przyciąganie utalentowanych jednostek.

\section{Marketing rekrutacyjny jako narzędzie employer brandingu}

Systematyczne obniżanie wskaźników bezrobocia oraz towarzyszący mu odpływ wykwalifikowanych pracowników poza granice kraju powodują, że coraz częściej mówi się o powrocie rynku pracownika. Ze strony pracodawców oznacza to rosnące trudności w pozyskiwaniu kompetentnych pracowników, zaś ze strony kandydatów rosnące ich oczekiwania wobec zatrudniającej organizacji. Sytuacja taka stwarza nowe wyzwania w obszarze zarządzania zasobami ludzkimi oraz rodzi zapotrzebowanie na nowe instrumenty oddziaływania na rynek pracy. Jednym z nich jest employer branding. Obejmuje on wszystkie działania, jakie podejmuje organizacja, skierowane do obecnych oraz potencjalnych pracowników, mające na celu budowanie jej wizerunku jako wyróżniającego się pracodawcy (Kozłowski, 2016, s. 13). Idea kształtowania wizerunku pracodawcy jest związana $\mathrm{z}$ praktyką przyciągania i zatrzymania utalentowanych jednostek $\mathrm{w}$ perspektywie rosnącego znaczenia kapitału ludzkiego jako czynnika konkurencyjności organizacji.

Kluczowym etapem, z punktu widzenia pozyskiwania kapitału ludzkiego, jest rekrutacja. W marketingowym podejściu do realizacji funkcji personalnej etap pozyskiwania pracowników postrzega się nie tylko jako zaopatrywanie firmy w wykwalifikowany potencjał kadrowy, ale przede wszystkim wizerunkowe oddziaływanie na rynek pracy (Pocztowski, 1998, s. 15). Rekrutacja jest jednym z najbardziej widocznych na zewnątrz działań przedsiębiorstwa, stanowiących element strategii kształtowania wizerunku pracodawcy.

Istotą rekrutacji jest komunikowanie się organizacji z rynkiem pracy w celu wzbudzenia zainteresowania jej ofertą wakatową oraz przyciągnięcia odpowiednich kandydatów. Pełni ona funkcję (Pocztowski, 1998, s. 74):

- informacyjną - przekazanie informacji o zapotrzebowaniu pracodawcy w zakresie zatrudnienia wraz z określeniem profilu pożądanego kandydata;

- motywacyjną - wywołanie zainteresowania właściwych grup zawodowych;

- autoselekcji - samoocena przez kandydata jego dopasowania do wymagań wakującego stanowiska.

Analizując współczesne działania organizacji w obszarze rekrutacji należy zauważyć, że zbiór wymienionych funkcji uległ wzbogaceniu o funkcję marketingową, znajdującą wyraz w kształtowaniu wizerunku przedsiębiorstwa poprzez: formę, treść i sposób komunikacji przekazów rekrutacyjnych. Rozwój funkcji marketingowej prowadzi do popularyzacji koncepcji marketingu rekrutacyjnego. Za cel swoich działań uznaje on wspieranie organizacji w osiągnięciu wizerunku „pracodawcy z wyboru” 
poprzez skutecznie dobrane formy rekrutacji (Wojtaszczyk, 2012, s. 90-91). Jego istotą jest przekonanie kandydatów do zainteresowania oferowanym produktem, jakim jest w tym przypadku wolne stanowisko pracy. Uwzględnienie perspektywy marketingowej w strategii rekrutacyjnej wymaga przede wszystkim:

- zdefiniowania grupy docelowej klientów oraz identyfikacji ich oczekiwań,

- dostosowania kanałów komunikacji i poinformowania o ofercie,

- umożliwienia konsumentowi wypróbowania produktu poprzez przedstawienie specyfiki pracy w firmie, $\mathrm{np}$. $\mathrm{w}$ formie wirtualnego spaceru po niej.

Realizację funkcji marketingowej rekrutacji ułatwia niewątpliwie środowisko wirtualne, stwarzając możliwość zastosowania narzędzi o szerokim spektrum oddziaływania, stąd też tradycyjne metody rekrutacji są coraz częściej wypierane przez narzędzia sieciowe. W procesie e-rekrutacji wykorzystywane są witryny internetowe, portale pośrednictwa pracy lub giełdy pracy, bazy CV, media społecznościowe czy marketing w wyszukiwarkach (Palonka, Porębska-Miąc, 2014, s. 978). Wśród najpopularniejszych działań tego typu wymienić należy (Zając, 2014, s. 94-95):

- pozycjonowanie strony organizacji w ogólnodostępnych wyszukiwarkach internetowych,

- internetowe strony kariery,

- filmy rekrutacyjne,

- $\quad$ kampanie wizerunkowe w serwisach społecznościach o charakterze zawodowym (Linkedin, Goldenline) oraz masowym (Facebook, Twitter),

- buzz recruting - kształtowanie wizerunku organizacji za pośrednictwem popularnego blogera, który na swoim blogu w pozytywny sposób opisuje dzień spędzony w danym przedsiębiorstwie (www.bydgoskiemarki.pl, 2016).

$\mathrm{Z}$ marketingowego punktu widzenia zarówno oferta zatrudnienia, jak i cały proces rekrutacyjny powinny być na tyle atrakcyjne, aby zainteresować kandydatów i zachęcić ich do aktywności. Wymaga to wychodzenia poza utarte schematy i sięgania po nowoczesne, dostosowane do preferencji kandydatów formy rekrutacji. Wśród najnowszych trendów w tym obszarze wymienić należy:

- grywalizację - jej istotą jest odwzorowanie specyfiki pracy w firmie w formie gry komputerowej, w celu sprawdzenia umiejętności kandydata w świecie wirtualnym. Hotel Marriott potencjalnym pracownikom proponuje grę „My Marriott Hotel”, w której muszą oni sobie poradzić z zadaniami związanymi z zarządzaniem hotelem. Z kolei L'Oréal oferuje grę „Reveal”, której uczestnicy biorą udział w kampanii wprowadzającej nowy produkt na rynek (Woźniak, 2015, s. 27-28);

- scouting - poszukiwanie kandydatów w ich naturalnym środowisku (np. obecnej pracy, sklepie, restauracji), w momencie, gdy przebywają oni w swojej strefie komfortu (www.chip.pl, 2014);

- crowdsourcing - tworzenie społeczności wokół danego pracodawcy i wykorzystanie w ten sposób stworzonej siatki powiązań w celach rekrutacyjnych, 
tj. do wyszukiwania odpowiednich kandydatów i zachęcania ich do aplikowania (Woźniak, 2014, s. 42);

- guerilla recruiting - obejmuje niekonwencjonalne formy przekazu (np. pisanie sprayem na murach czy organizowanie eventów, typu pokazy freestyle'u koszykarskiego), mające na celu wzbudzenie zainteresowania jak największej liczby kandydatów, przy stosunkowo niskich nakładach (www.experto24.pl, 2016).

Nowym trendem w obszarze rekrutacji jest też koncepcja Candidat Experience. Można ją zdefiniować jako kształtowanie doświadczenia kandydata w relacji z pracodawcą w czasie każdej styczności z marką, poczynając od momentu, gdy kandydat obserwuje działania organizacji i rozpatruje ją pod kątem potencjalnego pracodawcy, a kończąc na zatrudnieniu (Siwka, 2015, s. 42). Koncepcja podkreśla potrzebę budowania i utrzymywania pozytywnych więzi ze wszystkimi kandydatami, również tymi, którzy nie zostali zatrudnieni w danej procedurze rekrutacyjnej. Nieodłącznym jej elementem, a jednocześnie wyrazem marketingowego charakteru koncepcji, jest badanie zadowolenia wszystkich kandydatów po zakończonym procesie rekrutacji, gdyż ich opinie stanowią podstawowe źródło doskonalenia tego procesu. Można do tego celu wykorzystać ankietę lub zapożyczoną z marketingu metodę Mystery Applicant (inspirowaną Mystery Shopping), pozwalającą na prześledzenie całego procesu doboru, dzięki aktywnemu w nim udziałowi wyznaczonych osób, w celu identyfikacji błędów popełnianych na tym etapie realizacji funkcji personalnej.

Dbałość o Candidate Experience to niewątpliwie przejaw profesjonalizacji polityki personalnej. Koncepcja ta skupia się bowiem na poprawie standardów rekrutacyjnych. Oznacza ona wprawdzie dodatkowe zadania dla zespołu rekrutującego, związane z przygotowaniem i monitorowaniem skuteczności działań w tym obszarze, jednak ich wartością dodaną jest doskonalenie procesu rekrutacji, który - prowadzony w sposób właściwy - buduje pozytywny obraz organizacji na rynku pracy.

\section{Podsumowanie}

Wyzwaniem dla współczesnych organizacji jest już nie tylko pozyskiwanie klientów i budowanie z nimi długofalowych relacji, ale także przyciąganie i zatrzymanie utalentowanych jednostek, stanowiących najcenniejszy kapitał w gospodarce opartej na wiedzy. Aby spełnić oczekiwania coraz bardziej wymagających kandydatów, ewoluować muszą metody i narzędzia zarządzania zasobami ludzkimi. Coraz ważniejszą rolę w procesie pozyskiwania cennego kapitału ludzkiego odgrywa wytworzenie pozytywnego obrazu firmy jako potencjalnego pracodawcy, nawet wśród kandydatów, którzy nie zostali zatrudnieni. Zawsze mogą oni bowiem zostać klientami danej organizacji, dlatego warto zatroszczyć się o to, by byli również „ambasadorami marki”. 
Zapewnienie prawidłowego przebiegu procesów zarządzania zasobami ludzkimi we współczesnych uwarunkowaniach gospodarczych, gdy coraz trudniej o pozyskanie profesjonalistów, wymaga traktowania pracowników już zatrudnionych oraz kandydatów do pracy jako szczególną grupę interesariuszy, których potrzeby niewątpliwie winny być przedmiotem zainteresowania kadry menedżerskiej. Marketingowe podejście do procesu pozyskiwania kapitału ludzkiego rozpoczyna się od identyfikacji grup docelowych, ze szczególnym zwróceniem uwagi na oczekiwania młodych pracowników wkraczających na rynek pracy, tworzeniu atrakcyjnej oferty i informowaniu o niej za pomocą najbardziej efektywnego, w stosunku do danej grupy docelowej, zestawu narzędzi komunikacji. Istotnym elementem jest budowanie pozytywnych relacji ze wszystkimi kandydatami biorącymi udział w procesie rekrutacji. W konsekwencji konieczne staje się wykorzystanie narzędzi marketingowych, które mają służyć wsparciu efektywności funkcji personalnej. Marketingowe podejście do procesu pozyskiwania kapitału ludzkiego wymaga niewątpliwe zmiany mentalności pracodawców, którzy proces rekrutacji powinni postrzegać szerzej niż jedynie jako narzędzie zaopatrzenia kadrowego.

\section{BIBLIOGRAFIA}

[1] BARUK A.I., 2005, Rola marketingu personalnego we wspótczesnym przedsiębiorstwie, Annales Universitatis Mariae Curie-Skłodowska. Sectio H, Oeconomia, nr 39.

[2] BARUK A.I., 2006, Marketing personalny jako instrument kreowania wizerunku firmy, Difin, Warszawa.

[3] BARUK A.I., 2012, Rola marketingu personalnego w kształtowaniu wizerunku organizacji naukowej, „Prace Instytutu Lotnictwa”, nr 4 (225).

[4] BARUK A.I., 2014, Zewnętrzny marketing personalny jako element holistycznej orientacji organizacji, „Marketing i Rynek”, nr 3/2014.

[5] Bratton J., Gold J., 2003, Human resource management: theory and practice, Palgrave Macmillan, London.

[6] Bukowska U., 2006, Interesariusze a zarządzanie zasobami ludzkimi, Zeszyty Naukowe Akademii Ekonomicznej w Krakowie, nr 711.

[7] Ciepiela M., 2014, Wpływ interesariuszy na zarzadzanie przedsiębiorstwem, „Rynek - Społeczeństwo - Kultura", nr 3/2014.

[8] Gableta M., 2004, Człowiek i praca w zmieniającym się przedsiębiorstwie, Wydawnictwo Akademii Ekonomicznej im. Oskara Langego we Wrocławiu, Wrocław.

[9] Kozlowski M., 2012, Employer branding, Oficyna a Walters Kluwer business, Warszawa.

[10] Listwan T., 2010, Zarządzanie kadrami, Wydawnictwo C.H. Beck, Warszawa.

[11] Palonka J., PoręBSka-Miąc T., 2014, Rekrutacja w mediach społecznościowych (social recruitin), [w:] R. Knosala (red.), Innowacje w zarzadzaniu i inżynierii produkcji, Oficyna Wydawnicza PTZP, Opole.

[12] Pocztowski A., 1993, Rozwój potencjału pracy jako problem zarzadzania zasobami ludzkimi w przedsiębiorstwie, seria specjalna „Monografie”, AE w Krakowie, Kraków. 
[13] Pocztowski A., 1998, Zarzadzanie zasobami ludzkimi. Zarys problematyki i metod, Antykwa, Kraków.

[14] Schwan K., Seipel K. G., Marketing kadrowy, Wydawnictwo C. H. Beck, Warszawa 1997, s. 7.

[15] Siwka D., 2015, Candidat Experience, "Benefit", nr 7-8(43).

[16] Wojtaszczyк K., 2012, Employer branding, czyli zarzadzanie marka pracodawcy, Wyd. Uniwersytetu Łódzkiego, Łódź.

[17] WoźNIAK J., 2014, Crowdsourcing - IV etap rozwoju rekrutacji internetowej, „Zarządzanie Zasobami Ludzkimi”, nr 1.

[18] Woźniak J., 2015, Grywalizacja w zarządzaniu ludźmi, „Zarządzanie Zasobami Ludzkimi”, nr 2.

[19] ZAJĄC K., 2014, Marketing rekrutacyjny jako narzędzie employer, [w:] K. Kubiak (red.), Employer Branding $w$ teorii i praktyce, Wyższa Szkoła Promocji, Warszawa.

[20] Zbiegień-Maciąg L., 1996, Marketing personalny, Business Press, Warszawa.

\section{NETOGRAFIA}

[21] EXPERTO24, https://www.experto24.pl/firma/marketing-i-komunikacja/czym-jest-marketingpartyzancki-guerilla-marketing.html\#.WEc9ttXhA2w (8.12.2016).

[22] CHIP, http://www.chip.pl/news/wydarzenia/trendy/2014/10/grywalizacja-scouting-a-nawet...paczki (2.12.2016).

[23] BYDGOSKIEMARKI, http://www.bydgoskiemarki.pl/2016/09/03/marketing-rekrutacyjny-czylistosowac-nowoczesne-formy-rekrutacji-pracownikow/ (6.12.2016). 